\title{
Continued Shovel Test Investigations at the Historic Caddo Allen Phase Bowles Creek Site (41CE475), Cherokee County, Texas
}

Timothy K. Perttula

Heritage Research Center, Stephen F. Austin State University

Kevin Stingley

Texas Archeological Stewardship Network, Texas Historical Commission

Follow this and additional works at: https://scholarworks.sfasu.edu/ita

Part of the American Material Culture Commons, Archaeological Anthropology Commons, Environmental Studies Commons, Other American Studies Commons, Other Arts and Humanities Commons, Other History of Art, Architecture, and Archaeology Commons, and the United States History Commons

Tell us how this article helped you.

This Article is brought to you for free and open access by the Center for Regional Heritage Research at SFA ScholarWorks. It has been accepted for inclusion in Index of Texas Archaeology: Open Access Gray Literature from the Lone Star State by an authorized editor of SFA ScholarWorks. For more information, please contact cdsscholarworks@sfasu.edu. 
Continued Shovel Test Investigations at the Historic Caddo Allen Phase Bowles Creek Site (41CE475), Cherokee County, Texas

\section{Creative Commons License}

\section{(c) (1) (8)}

This work is licensed under a Creative Commons Attribution-NonCommercial 4.0 International License 


\title{
Continued Shovel Test Investigations at the Historic Caddo Allen Phase Bowles Creek Site (41CE475), Cherokee County, Texas
}

\author{
Timothy K. Perttula and Kevin Stingley
}

\section{Introduction and Past Investigations}

The Bowles Creek site (41CE475) on Bowles Creek in the Neches River basin in East Texas (Figure 1) is an important and well-preserved Historic Caddo Allen phase habitation site on a low alluvial rise not far north of the current channel of Bowles Creek (Perttula and Stingley 2016, 2017; Perttula et al. 2016). This article summarizes the archaeological findings from the February 2016 excavation of 18 additional shovel tests (ST 40-48 and ST 50-60) at the site, placed between 10-25 m north of the Bowles Creek channel, and excavated in an attempt to clarify the subsurface character and depth of the archaeological deposits in this part of the site given the recovery of ancestral Caddo sherds from 100-140 cm bs in the Bowles Creek cut bank (Perttula and Stingley 2017).

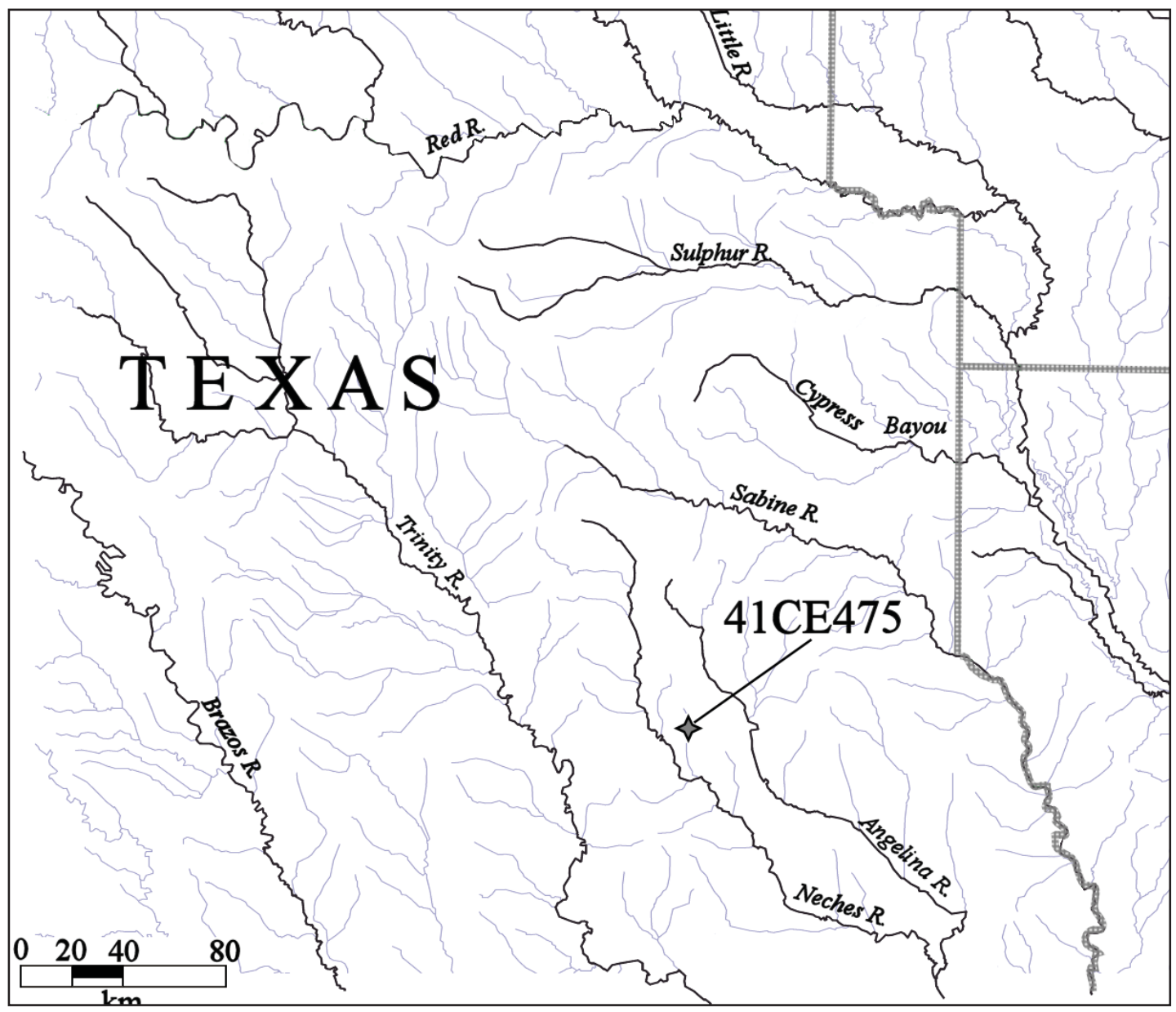

Figure 1. The location of the Bowles Creek site (41CE475) in East Texas. 
The first investigations included a surface collection, along with the excavation of a number of shovel tests as well as three units (Units 1-3, generally 1 x $1 \mathrm{~m}$ in size) done by Stingley at the site (Perttula et al. 2016). These initial archaeological investigations at the Bowles Creek site recovered 617 ceramic sherds (Perttula et al. 2016:Table 13), of which 461 were decorated. A single radiocarbon date has been obtained on a piece of unburned animal bone from Unit $3,40-50 \mathrm{~cm}$ bs, at the site. The radiocarbon age of this AMS sample from the Bowles Creek site is $410 \pm 24$ years B.P. (D-AMS 11799), or A.D. $1540 \pm 24$. The 2 sigma calibration (95 percent probability), using IntCal13 (Reimer et al. 2013), is A.D. $1525 \pm 84$. This result suggests that there are also Frankston phase (ca. A.D. 1400-1650) archaeological deposits preserved at the site.

A second sample of material culture remains from the Bowles Creek site was obtained by Stingley in July and August 2015, primarily from areas recently disturbed by wild hogs (see Perttula and Stingley 2016:Figure 2). This surface collection recovered another 337 ceramic sherds, including 206 decorated sherds (Perttula and Stingley 2016a:Table 1). There were also a small number of unburned animal bones and teeth in this surface collection, as well as a gray novaculite Cuney arrow point..

More recently, 14 more shovel tests were excavated across the site, including two shovel tests near the artificial cut of the Bowles Creek channel, and all but one contained ancestral Caddo artifacts in a reddish-brown sandy loam alluvial deposit (Perttula and Stingley 2017). Furthermore, the creek cut banks were examined, and Caddo sherds were noted buried in the alluvial sediments at depths between $100-140 \mathrm{~cm}$ bs; these deposits may merge with the archaeological deposits encountered in other shovel tests north of the cut bank. A single $1 \times 1 \mathrm{~m}$ unit (Unit BC-2) was also excavated in the central part of the rise, adjacent to Unit 3 excavated by Stingley in 2015 (see Perttula et al. 2016:Figure 12). The purpose of excavating Unit BC-2 was to assess the subsurface character of the archaeological deposits and determine if features were present in this part of the site.

The archaeological deposits in Unit BC-2 were a reddish-brown sandy loam to $50 \mathrm{~cm}$ bs. At $40 \mathrm{~cm}$, the tops of two circular post hole stains of a dark brown sandy loam were identified adjacent to each other in the floor of the unit (Perttula and Stingley 2016b:Figure 3a). The post holes (Stains 4 and 5) were 21-22 cm in diameter, with charcoal flecks and animal bone. The Stain 4 post hole had straight sides and a rounded bottom and extended to $92 \mathrm{~cm}$ bs, while Stain 5 extended to $74 \mathrm{~cm}$ bs, and also had straight sides and a rounded bottom. The size of the post holes in the unit suggested that a portion of a Caddo house structure was encountered in the excavations. Artifacts recovered in Unit BC-2 included plain and decorated ceramic vessel sherds $(n=144)$, animal bone $(n=20)$, wood charcoal $(n=11)$, charred nutshells $(\mathrm{n}=3)$, lithic debris $(\mathrm{n}=3)$, and a polished quartzite pebble resting at $31 \mathrm{~cm}$ bs. The most concentrated deposits of archaeological material culture remains in the unit occurred between 10-30 $\mathrm{cm}$ bs (Perttula and Stingley 2016b:Table 3), with animal bone pieces most common between $30-40 \mathrm{~cm}$ bs; the majority of the wood charcoal and all of the nutshell came from the fill of the Stain 4 and 5 post holes.

In addition to the excavation of shovel tests and a $1 \times 1 \mathrm{~m}$ unit, the remote sensing of a 2400 square meters (ca. 0.6 acres) of the archaeological deposits at the Bowles Creek site was conducted by McKinnon (2016). The remote sensing detected two probable intact structures, ca. $5 \mathrm{~m}$ in diameter in the central and eastern part of the remote sensing grid (McKinnon 2016:Figure 3) as well as a partial circular radius of post holes from another circular structure in the south central part of the remote sensing grid, closer to the Bowles Creek channel.

\section{Renewed Shovel Testing near the Bowles Creek Channel}

All 18 of the most recently excavated shovel tests at the Bowles Creek site contain archaeological deposits between $0-100 \mathrm{~cm}$ bs. The shovel tests cover a $15 \times 60 \mathrm{~m}$ area approximately $10-25 \mathrm{~m}$ north of the northern cut bank of Bowles Creek (Figure 2). The archaeological deposits are a reddish-brown sandy loam from $0-65 \mathrm{~cm}$ bs, and are underlain by a dark reddish-brown sandy loam. The clay B-horizon was encountered only in ST $55(77 \mathrm{~cm} \mathrm{bs)}$ and ST $58(88 \mathrm{~cm} \mathrm{bs})$, in the northeastern part of the investigated area. 


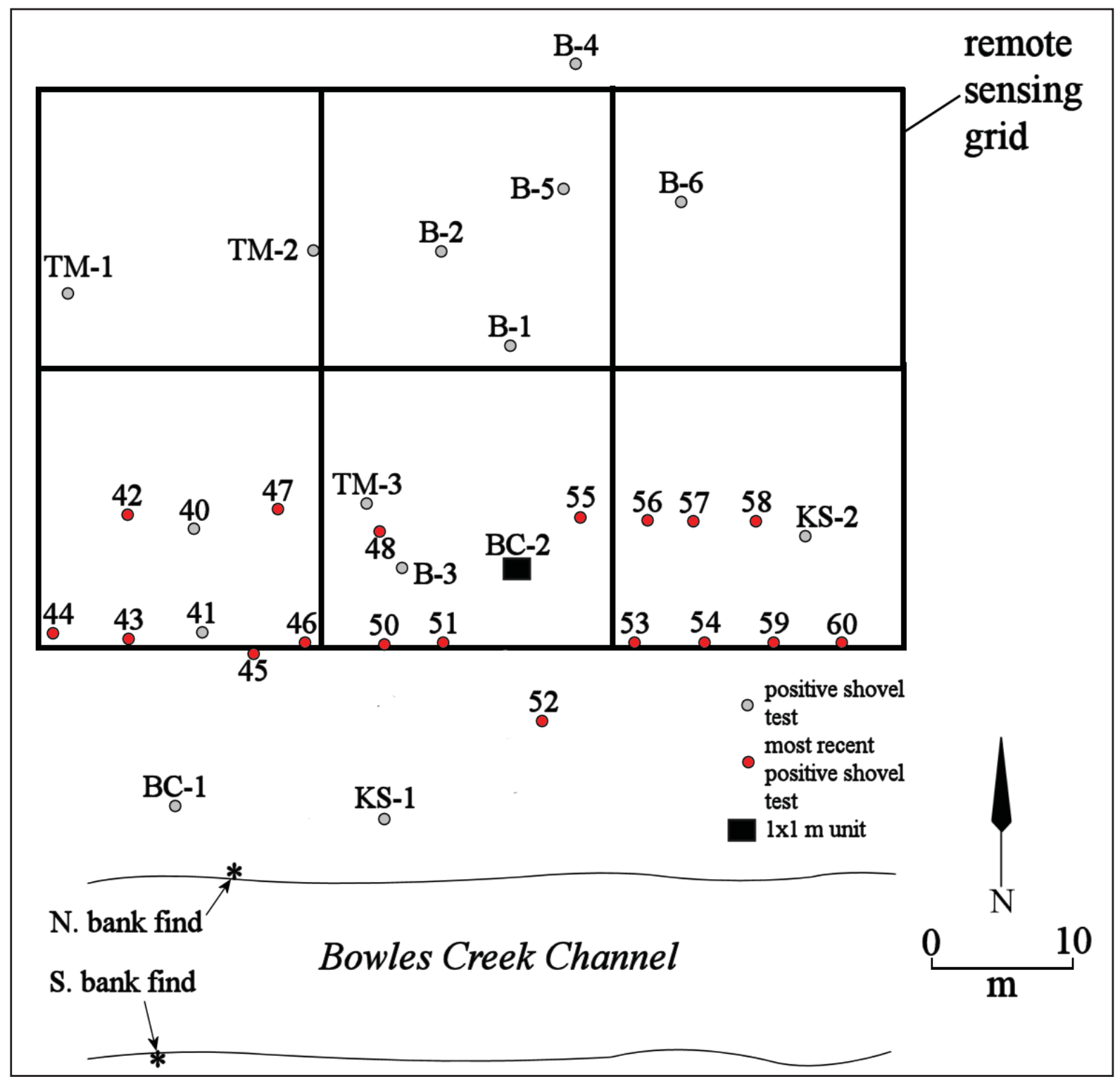

Figure 2. The location of recent shovel tests in and immediately adjacent to the remote sensing grid at the Bowles Creek site (41CE475). The shovel tests discussed in this article are highlighted in red.

Artifact densities in these positive shovel tests range from 5-34 specimens, or a mean of 19.5 artifacts per positive shovel test (Table 1); this is equivalent to ca. 156.0 artifacts per square meter of archaeological deposits. The highest densities of artifacts are in the central part of the investigated area (see Figure 2). Four of the shovel tests with the highest artifact densities also have burned or unburned animal bones and two of these shovel tests have charred nutshells. About 93 percent of the recovered artifacts from this round of shovel testing are plain and decorated ceramic vessel sherds, followed by animal bone (4 percent), lithic debris (3 percent), and wood charcoal/nutshell (1.7 percent). 
Table 1. Artifacts recovered in the most recent shovel testing at the Bowles Creek site.

\begin{tabular}{llllllllll}
\hline ST No. & DS & PS & Pi & FT & GS & LD & AB & WC/NS & N \\
\hline 42 & 12 & 3 & - & - & 1 & - & - & - & 16 \\
43 & 6 & 4 & - & - & - & 1 & - & $1 /-$ & 12 \\
44 & 1 & 3 & - & - & - & 1 & - & - & 5 \\
45 & 11 & 3 & - & - & - & - & - & - & 14 \\
46 & 5 & 9 & - & - & - & - & - & - & 14 \\
47 & 19 & 4 & - & - & - & - & - & - & 23 \\
48 & 21 & 8 & - & - & - & - & 2 & - & 31 \\
50 & 13 & 4 & - & - & - & - & - & - & 22 \\
51 & 17 & 5 & - & - & - & - & - & - & 28 \\
52 & 15 & 4 & - & - & - & - & 7 & $1 / 1$ & 20 \\
53 & 21 & 2 & - & - & - & - & 4 & - & 28 \\
54 & 11 & 8 & - & 1 & - & - & - & - & 34 \\
55 & 19 & 9 & - & - & - & - & - & - & 14 \\
56 & 14 & 12 & 1 & 1 & 3 & - & - & $1 / 3$ \\
57 & 8 & 5 & - & - & - & 1 & - & - & 20 \\
58 & 10 & 6 & - & - & - & 1 & - & - & 9 \\
59 & 10 & 5 & - & - & - & 4 & 1 & - & 351 \\
60 & 6 & 3 & - & - & - & - & - & - & $2 / 4$ \\
\hline Totals & 219 & 97 & 1 & 1 & 2 & 11 & 14 & 22 \\
\hline
\end{tabular}

$\mathrm{DS}=$ decorated sherd; $\mathrm{PS}=$ plain sherd; $\mathrm{Pi}=$ pipe sherd; $\mathrm{FT}=$ flake tool; $\mathrm{GS}=$ ground stone tool; $\mathrm{LD}=$ lithic debris; $\mathrm{AB}=$ animal bone; $\mathrm{WC}=$ wood charcoal; $\mathrm{NS}=$ nutshell

As previously mentioned, ancestral Caddo archaeological deposits are present from at least 0-100 $\mathrm{cm}$ bs in the alluvial sediments along Bowles Creek (Table 2), considering the depth of ceramic sherds found buried in the cut bank of the creek. The highest densities, however, in this set of shovel tests are from 0-60 cm bs; the artifacts from these deposits represent approximately 84 percent of the recovered assemblage, with 9.7 percent of the artifacts coming from $60-80 \mathrm{~cm}$ bs, and only 6.6 percent from $80-100 \mathrm{~cm}$ bs. Animal bone and wood charcoal/charred nutshells are concentrated between $20-80 \mathrm{~cm}$ bs, with those found at greater depths likely to be the result of the presence of preserved cultural features containing organic remains below $60 \mathrm{~cm}$ bs.

Table 2. Depth of artifacts recovered in the most recent shovel testing at the Bowles Creek site.

\begin{tabular}{lccccccccc}
\hline $\begin{array}{l}\text { Depth } \\
\text { (cm bs })\end{array}$ & DS & PS & Pi & FT & GS & LD & AB & WC/NS & N \\
\hline $0-20$ & 73 & 31 & - & - & - & 4 & - & - & 108 \\
$20-40$ & 61 & 27 & - & - & - & 1 & 2 & - & 91 \\
$40-60$ & 50 & 29 & 1 & 1 & - & 4 & 8 & $1 / 1$ & 95 \\
$60-80$ & 19 & 6 & - & - & 1 & 1 & 3 & $1 / 3$ & 34 \\
$80-100$ & 15 & 5 & - & - & 1 & 1 & 1 & - & 23 \\
\hline Totals & 219 & 97 & 1 & 1 & 2 & 11 & 14 & $2 / 4$ & 351 \\
\hline
\end{tabular}

$\mathrm{DS}=$ decorated sherd; $\mathrm{PS}=$ plain sherd; $\mathrm{P}$ =pipe sherd; $\mathrm{FT}=$ flake tool; $\mathrm{GS}=$ ground stone tool; $\mathrm{LD}=$ lithic debris; $\mathrm{AB}=$ animal bone; WC=wood charcoal; NS=nutshell 


\section{Material Culture Remains}

\section{Ceramic Vessel Sherds}

This ceramic vessel sherd sample, as with the others from the Bowles Creek site, is predominantly comprised of sherds from grog-tempered vessels, as 87.7 percent are tempered with grog (i.e., crushed sherds). The remaining 12.3 percent of the sherds are from bone-tempered vessels (Table 3 ). The proportion of bone-tempered vessel sherds is virtually the same in the plain wares (13.4 percent) and utility wares (12.4 percent), but only 5.9 percent of the fine ware sherds are from vessels manufactured with crushed and burned bone temper.

Table 3. Ceramic wares in the February 2016 sample from the Bowles Creek site.

\begin{tabular}{lccc}
\hline Ware & Grog-tempered & Bone-tempered & N \\
\hline Plain & 84 & 13 & 97 \\
Utility & 177 & 25 & 202 \\
Fine & 16 & 1 & 17 \\
\hline Totals & 277 & 39 & 316 \\
\hline
\end{tabular}

The plain to decorated sherd ratio (P/DR) in this sherd sample is 0.44 . Of the 219 decorated sherds, only 7.8 percent are from fine ware vessels with engraved decorative elements. More than 92 percent of the decorated sherds, and 91 percent of the rim sherds, are from utility ware vessels (see Table 3), almost exclusively from jars.

The utility wares from the Bowles Creek site are dominated by sherds with brushed, brushed-incised, and brushed-punctated decorative elements (Table 4). Almost 86 percent of all the decorated sherds have brushing marks, including sherds with brushed-incised (Figure 3a) and brushed-punctated (Figure 3b-d) decorative elements. These decorated sherds are from Bullard Brushed vessels, with the exception of two Spradley Brushed-Incised body sherds with sets of incised lines drawn over areas with parallel brushing. The brushed to plain sherd ratio in this sample is 1.94 , and the brushed to other wet paste sherd ratio is 7.83 .

Table 4. Decorative methods and decorative elements represented in the February 2016 sample from the Bowles Creek site.

\begin{tabular}{llll}
\hline Decorative method and decorative element & Rim & Body & N \\
\hline
\end{tabular}

\section{Utility Ware}

\section{Brushed}

horizontal brushed

opposed brushed

overlapping brushed

parallel brushed

vertical brushed

$\begin{array}{lll}3 & - & 3 \\ - & 7 & 7 \\ - & 4 & 4 \\ - & 162 & 162 \\ 1 & 1 & 2\end{array}$


Table 4. Decorative methods and decorative elements represented in the February 2016 sample from the Bowles Creek site, cont.

\begin{tabular}{|c|c|c|c|}
\hline Decorative method and decorative element & Rim & Body & $\mathrm{N}$ \\
\hline \multicolumn{4}{|l|}{ Utility Ware, cont. } \\
\hline \multicolumn{4}{|l|}{ Brushed-Incised } \\
\hline opposed brushed-incised & - & 1 & 1 \\
\hline parallel brushed-incised & - & 1 & 1 \\
\hline parallel incised lines and opposed brushing marks & - & 1 & 1 \\
\hline parallel brushed and overlying opposed incised lines & - & 1 & 1 \\
\hline parallel brushed and overlying parallel incised lines & - & 1 & 1 \\
\hline \multicolumn{4}{|l|}{ Brushed-Punctated } \\
\hline $\begin{array}{l}\text { diagonal brushed and tool punctated row beneath } \\
\text { the lip }\end{array}$ & 1 & - & 1 \\
\hline $\begin{array}{l}\text { horizontal brushed and tool punctated row beneath } \\
\text { the lip }\end{array}$ & 1 & - & 1 \\
\hline $\begin{array}{l}\text { parallel brushed and tool punctated rows pushed } \\
\text { through the brushing }\end{array}$ & - & 1 & 1 \\
\hline $\begin{array}{l}\text { vertical brushed and tool punctated row beneath } \\
\text { the lip }\end{array}$ & 2 & - & 2 \\
\hline \multicolumn{4}{|l|}{ Grooved } \\
\hline straight groove & - & 1 & 1 \\
\hline \multicolumn{4}{|l|}{ Incised } \\
\hline parallel incised lines & - & 2 & 2 \\
\hline straight incised line & - & 7 & 7 \\
\hline \multicolumn{4}{|l|}{ Incised-Punctated } \\
\hline straight incised line and adjacent tool punctated row & - & 1 & 1 \\
\hline \multicolumn{4}{|l|}{ Neck Banded } \\
\hline horizontal neck banded & 1 & - & 1 \\
\hline \multicolumn{4}{|l|}{ Punctated } \\
\hline tool punctated rows & 1 & 1 & 2 \\
\hline \multicolumn{4}{|l|}{ Fine Ware } \\
\hline \multicolumn{4}{|l|}{ Engraved } \\
\hline horizontal engraved lines & 1 & 1 & 2 \\
\hline linear tick marks & - & 1 & 1 \\
\hline opposed engraved lines & - & 1 & 1 \\
\hline straight engraved line & - & 6 & 6 \\
\hline straight engraved line with excised triangular tick marks & - & 5 & 5 \\
\hline straight engraved line and linear tick marks & - & 1 & 1 \\
\hline \multicolumn{4}{|l|}{ Engraved-Brushed } \\
\hline horizontal engraved line/horizontal brushed & - & 1 & 1 \\
\hline Totals & 11 & 208 & 219 \\
\hline
\end{tabular}




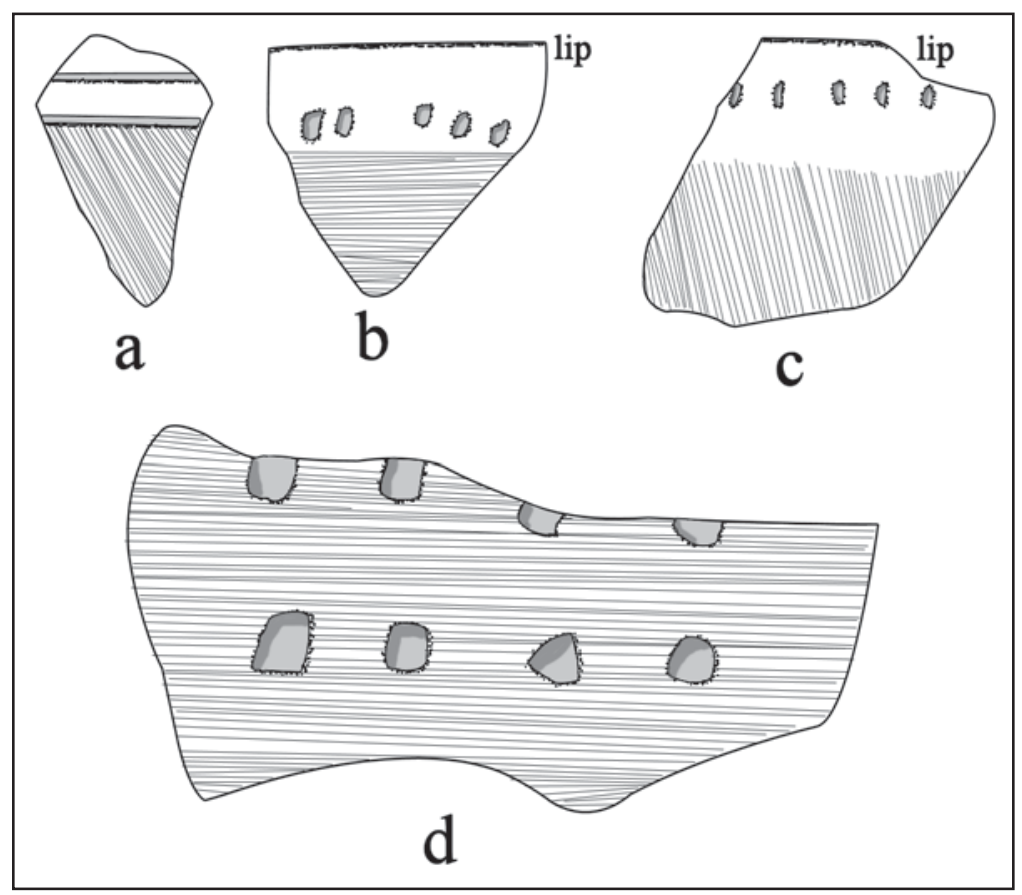

Figure 3. Selected decorative elements on utility ware sherds from the Bowles Creek site: a, brushedincised; b-d, brushed-punctated.

Other utility wares include one Lindsey Grooved body sherd, a La Rue Neck Banded rim sherd, and a few other sherds with wet paste decorative elements. This includes sherds with simple incised lines (4.1 percent of the decorated sherds), one incised-punctated body sherd ( 0.5 percent), and rim or body sherds with rows of tool punctations (0.9 percent) (see Table 4$)$.

Seven of the 17 fine ware sherds, several from carinated bowls, in this sample of ceramic vessel sherds from the Bowles Creek site are from Patton Engraved vessels. These sherds have either linear tick marks $(n=2)$ or small excised triangles on sherds with a single straight engraved line (see Table 4). None of the other engraved or engraved-brushed sherds in this assemblage are identifiable to a defined East Texas Caddo ceramic type.

Table 5 summarizes the character of the ceramic vessel sherd assemblage $(n=1538)$ from the Bowles Creek site based on the different surface, shovel test, and 1 x $1 \mathrm{~m}$ unit excavation conducted here since 2015. The assemblage is much like other Historic Caddo Allen phase components that have been studied in the Bowles Creek valley (see Perttula and Stingley 2016b:Table 15). The assemblage includes plain wares, utility wares, and fine wares, and the utility ware sherds are dominant; the P/DR is low (0.47), also consistent with an Allen phase component in this part of the Neches River basin. The sherds are predominantly from grog-tempered vessels, and these vessels (of the Bullard Brushed type and Spradley Brushed-Incised) are decorated primarily with brushing marks (83.2 percent), and with few sherds from fine ware vessels (8.0 percent), most of which are from Patton Engraved vessels. Other utility wares in the assemblage are represented by a few sherds of Lindsey Grooved and La Rue Neck Banded, and the incised and incised-punctated sherds are likely from Maydelle Incised vessels. 
Table 5. Ceramic sherd assemblage summary from the Bowles Creek site.

\begin{tabular}{ll}
\hline Attribute & Bowles Creek \\
\hline No. of sherds & 1538 \\
No. of decorated sherds & 1047 \\
Plain ware & $31.9 \%$ \\
Utility ware & $62.8 \%$ \\
Fine ware & $5.3 \%$ \\
& \\
P/DR & 0.47 \\
Brushed/Plain Ratio & 1.78 \\
Brushed/OWP Ratio & 7.09 \\
& \\
Grog-tempered & $89.1 \%$ \\
Bone-tempered & $10.9 \%$ \\
& \\
Engraved & $7.2 \%$ \\
Engraved-brushed & $0.2 \%$ \\
Engraved-punctated & $0.2 \%$ \\
Trailed & $0.4 \%$ \\
& \\
Brushed & $80.6 \%$ \\
Brushed-Appliqued & $0.1 \%$ \\
Brushed-Incised & $1.3 \%$ \\
Brushed-Punctated & $1.2 \%$ \\
Grooved & $0.4 \%$ \\
Incised & $5.2 \%$ \\
Incised-Punctated & $0.3 \%$ \\
Neck Banded & $0.3 \%$ \\
Pinched & $0.7 \%$ \\
Punctated & $2.1 \%$ \\
\hline & \\
\hline &
\end{tabular}

$\mathrm{P} / \mathrm{DR}=$ plain/decorated sherd ratio; $\mathrm{OWP}=$ other wet paste sherds

\section{Ceramic Pipe Sherds}

A large section of the stem and lower bowl of a grog-tempered elbow pipe was recovered in ST 56 (40-60 cm bs). The pipe has five rows of small tool punctations on the stem (Figure 4). Jackson (1933:75, 1936:Plate 28) refers to these as Neches pipes, and they have rows of punctations on the stem and/or heel and bowl.

The stem of the pipe is $33.9 \mathrm{~mm}$ in length, $18.9 \mathrm{~mm}$ in width and in exterior diameter. The interior bore hole is $10.5 \mathrm{~mm}$ in diameter; the flat lip of the stem is $4.3 \mathrm{~mm}$ thick. The lower bowl diameter is $18.9 \mathrm{~mm}$, while the bore hole connecting the stem and bowl is only $6.0 \mathrm{~mm}$ in diameter (see Figure 4). 


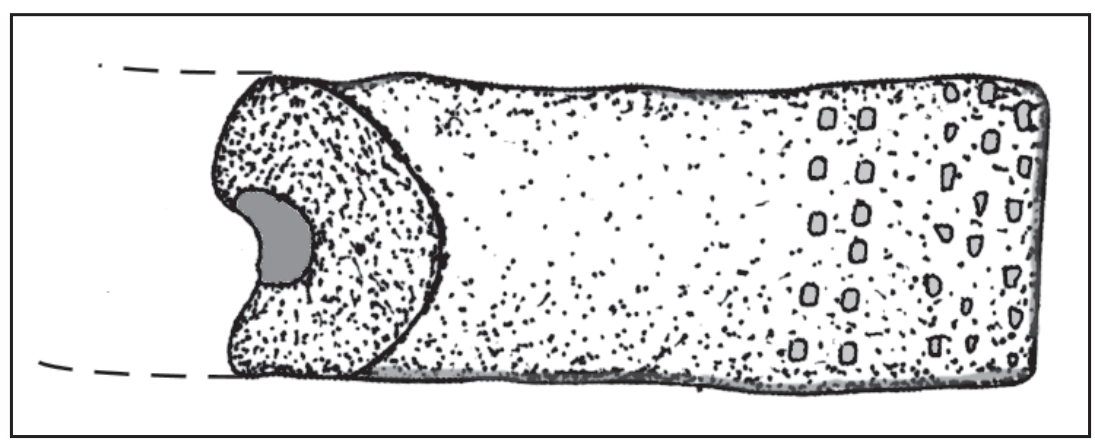

Figure 4. Neches pipe sherd from the Bowles Creek site.

\section{Ground Stone and Flake Tools}

The two ground stone tools are from ST 42 and ST 56. The ground stone tool in ST $42(80-100 \mathrm{~cm}$ bs) is a $56 \times 33 \times 26 \mathrm{~mm}$ fragment of ferruginous sandstone, probably from a mano or pitted stone. The second ground stone tool (ST $56,78 \mathrm{~cm}$ bs) is a quartzite mano with two smoothly ground surfaces. The one flake tool is from ST $54(40-60 \mathrm{~cm}$ bs). It has bilateral flaking/use wear on a cortical flake of a nonlocal light gray chert. The two use-worn areas are $24 \mathrm{~mm}$ and $27 \mathrm{~mm}$ in length.

\section{Lithic Debris}

The few pieces of lithic debris $(n=11)$ in this artifact sample from the Bowles Creek site are flakes detached from several lithic raw materials, including: brownish-gray chert ( $\mathrm{n}=1,0$ percent cortical), dark gray chert ( $n=2,50$ percent cortical), bluish-gray chert ( $n=3,0$ percent cortical), Manning Fused Glass $(n=1,0$ percent cortical), petrified wood $(n=3,67$ percent cortical), and ferruginous sandstone $(n=1,100$ percent); this flake may be the product of the shaping of a ground stone tool. The cherts are from nonlocal sources, probably either in gravels of the Neches River or from Central Texas sources to the west of the Bowles Creek valley, while Manning Fused Glass sources are in the Manning Formation, ca. 70 $\mathrm{km}$ to the south (Brown 1976:Figure 3). Manning Fused Glass is also present in the Historic Caddo Allen phase component at the Deshazo site in the Angelina River basin (Brown 1976:199).

\section{Animal Bone and Charred Plant Remains}

Animal bones $(n=14)$ and charred plant remains $(n=6)$ are preserved in a few of the most recently excavated shovel tests at the Bowles Creek site (see Table 1). The animal bone came from $20-100 \mathrm{~cm}$ bs, but was concentrated between $40-60 \mathrm{~cm}$ bs, while the charred plant remains came from $40-80 \mathrm{~cm}$ bs (see Table 2). None of the animal bone has been identified, but the pieces are generally small fragments. They include nine unburned pieces and five burned animal bones. The charred plant remains include two pieces of wood charcoal and four Carya sp. nutshells.

\section{Spatial Distribution of Artifacts}

The excavation of many positive shovel tests in and immediately adjacent to the remote sensing grid disclosed that there are two concentrations of ancestral Caddo ceramic vessel sherds in the southern part of the grid, about 10-30 m north of the Bowles Creek channel (Figure 5a). Both concentrations are marked by densities greater than ca. 176 sherds per square meter of archaeological deposits, and deposits with densities of sherds greater than ca. 112 sherds per square meter cover a ca. 50 x $20 \mathrm{~m}$ area. These ceramic vessel sherd concentrations represent the locations of well-preserved habitation deposits likely associated with at least two Caddo house structures (cf. McKinnon 2016:Figure 3). 

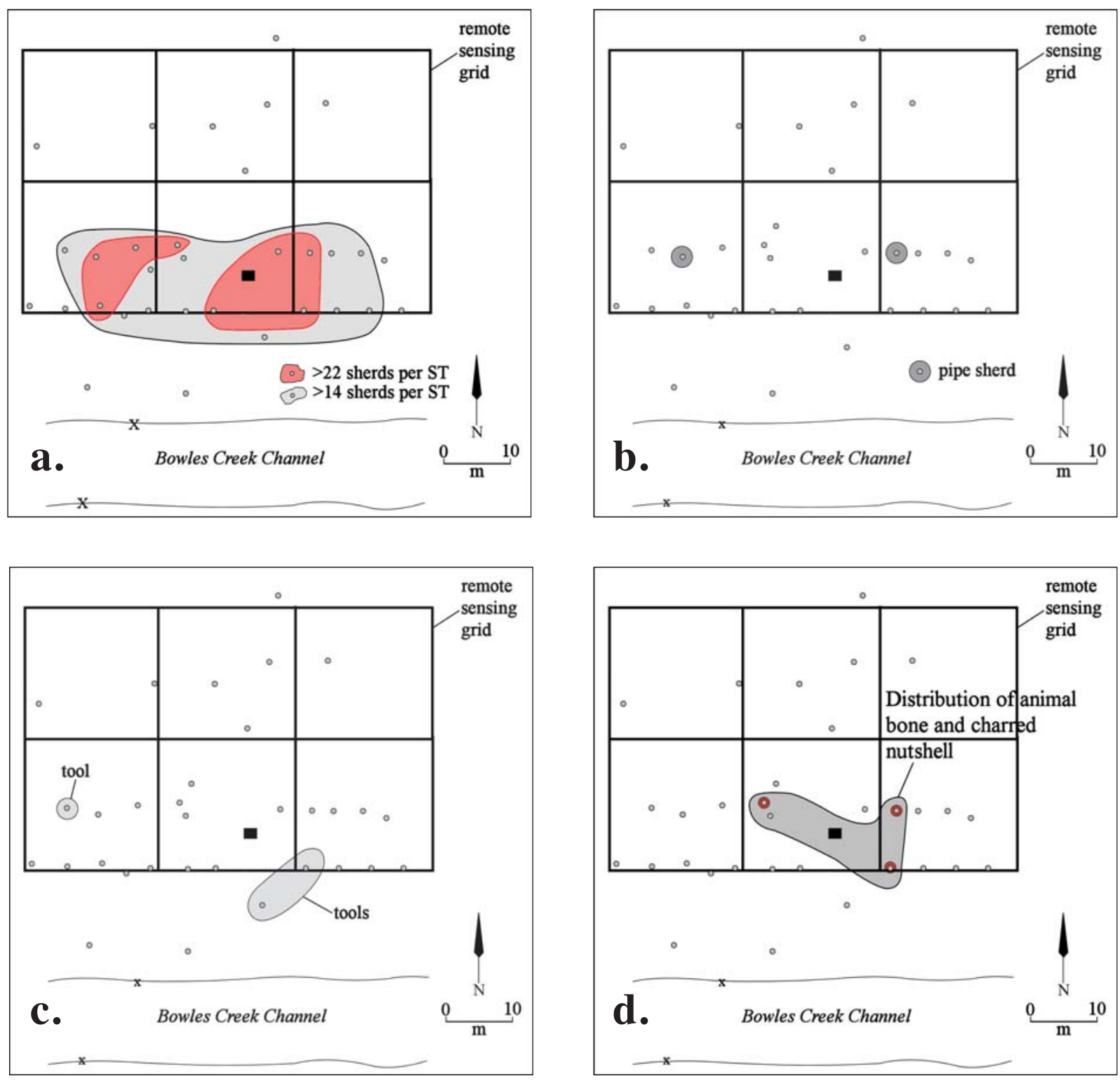

Figure 5. Spatial distribution of ancestral Caddo artifacts at the Bowles Creek site: a, ceramic vessel sherds; b, pipe sherds; c, tools; d, animal bone and charred nutshells.

The two ceramic elbow pipe sherds recovered in the shovel testing fall within the two ceramic vessel sherd concentrations (see Figure 5b), as do also the chipped and ground stone tools (see Figure 5c). Shovel tests with animal bone fragments and pieces of charred nutshells are in a ca. $20 \times 10 \mathrm{~m}$ area that falls within the distribution of both vessel sherd concentrations (see Figure 5d).

\section{Summary and Conclusions}

The continued archaeological investigations at the Bowles Creek site (41CE475) includes the excavation in February 2016 of 18 shovel tests in an area 10-25 m north of the northern cut bank along Bowles Creek. These shovel tests were excavated to better define the subsurface character of the archaeological deposits at the site, and assess the relationship between the archaeological deposits here and those in the cut bank, where ceramic vessel sherds have been recovered between $100-140 \mathrm{~cm}$ bs. This work has demonstrated that there are substantial archaeological deposits of Historic Caddo Allen phase age in 
this area that extend to at least $100 \mathrm{~cm}$ bs in many of the shovel tests, including preserved animal bone and charred plant remains in a few of the shovel tests. The spatial distribution of ceramic vessel sherds, ceramic elbow pipe sherds, chipped and ground stone tools, and animal bone as well as charred nutshells are concentrated in a ca. $50 \times 20 \mathrm{~m}$ area not far north of the Bowles Creek channel, and likely represent habitation debris from the occupation and use of at least two Historic Caddo house structures on this part of the Bowles Creek site. The recovered material culture remains include 316 sherds, 219 of which have decorative elements, one Neches style ceramic elbow pipe, three chipped or ground stone tools, and a small amount of lithic debris from both local and non-local raw material sources.

\section{Acknowledgments}

We appreciate the permission given by the landowner, Mr. Lonnie Lindsey, to conduct these investigations at the Bowles Creek site. Lance Trask prepared the figures in this article.

\section{References Cited}

Brown, K. M.

1976 Fused Volcanic Glass from the Manning Formation. Bulletin of the Texas Archeological Society 47:189207.

Jackson, A. T.

1933 Some Pipes of East Texas. Bulletin of the Texas Archeological and Paleontological Society 5:69-86.

1936 A Perpetual Fire Site. Bulletin of the Texas Archeological and Paleontological Society 8:134-174.

McKinnon, D. P.

2016 Report on Magnetic Gradient Surveys at Four Caddo Sites in East Texas. University of Central Arkansas, Conway.

Perttula, T. K. and K. Stingley

2016 Additional Material Culture Remains from the Bowles Creek Site (41CE475) in Cherokee County, Texas. Journal of Northeast Texas Archaeology 67:7-14.

2017 Renewed Archaeological Investigations at the Bowles Creek (41CE475), Cornfield (41CE476), and Peach Orchard (41CE477) Sites in the Bowles Creek Valley, Cherokee County, Texas. Journal of Northeast Texas Archaeology 71, this volume.

Perttula, T. K., K. Stingley, and M. Walters

2016 Historic Caddo Archaeological Sites in Cherokee County, Texas. Journal of Northeast Texas Archaeology 65:1-24. 


\title{
Appendix 1, The Findings from Shovel Tests 61-71 at the Bowles Creek Site (41CE475)
}

\author{
Timothy K. Perttula and Kevin Stingley
}

Shovel tests 61-71 at the Bowles Creek site were excavated in March 2016 to further investigate the archaeological deposits within ca. 5-15 m of the current Bowles Creek channel (Figure A-1). Earlier shovel testing here (elsewhere in this article) indicated that there are substantial archaeological deposits with a considerable density of artifacts per square meter, as well as the likelihood of intact cultural features.

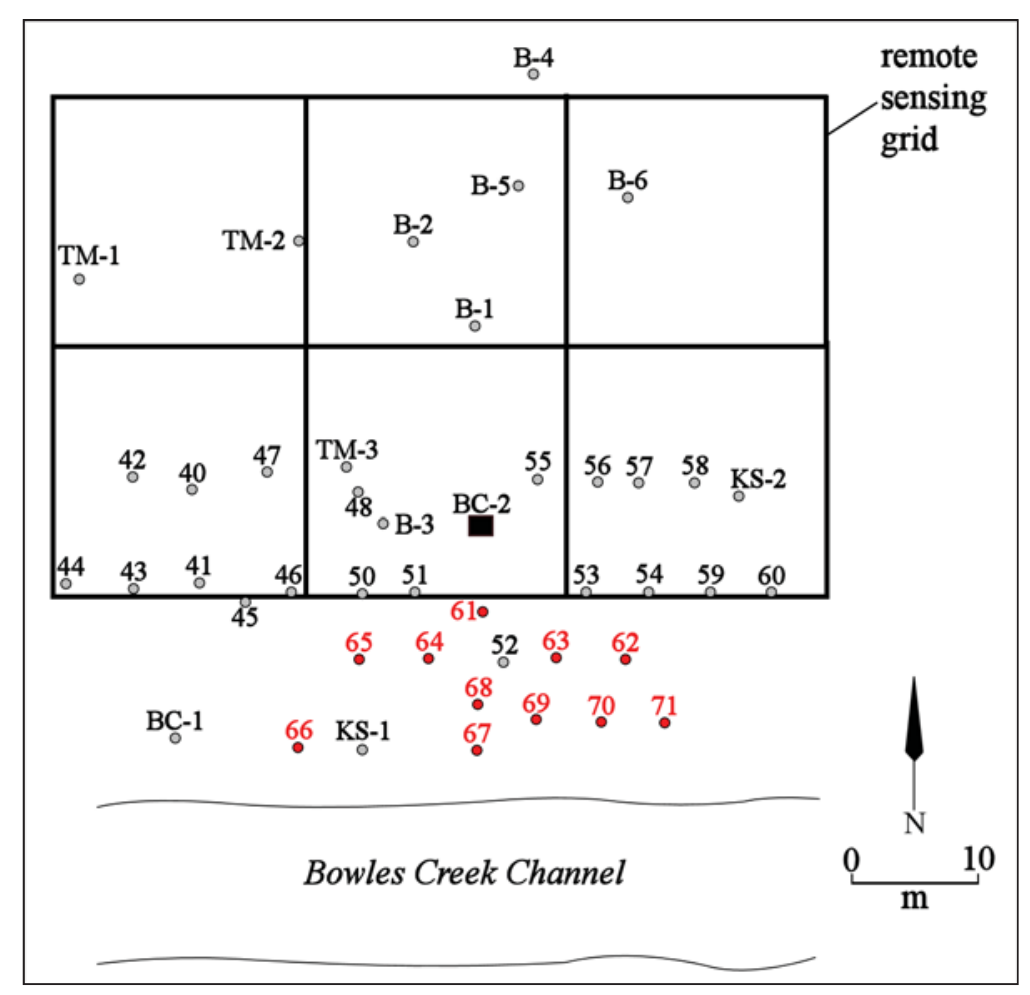

Figure A-1. Location of ST 61-71 and other shovel tests and units at the Bowles Creek site (41CE475).

Eight of the 11 shovel tests in this part of the Bowles Creek site contain archaeological deposits with ceramic sherds, lithic debris, animal bone, charred plant remains, and pieces of burned clay (Table A-1). The mean density of artifacts in these positive shovel tests is 28.3 , or ca. 226 artifacts per square meter of archaeological deposits. The highest density of artifacts occurs in ST 61, and this shovel test also has a number of pieces of burned and unburned animal bones, charred nutshells and wood charcoal, pieces of mussel shell, and burned clay with ash chunks. It is likely that ST 61 penetrated a cultural feature, perhaps the remnants of a Caddo house structure, hearth, or large pit. 
Table A-1. Artifacts recovered in ST 61-71 at the Bowles Creek site.

\begin{tabular}{lllllllll}
\hline ST No. & DS & PS & LD & AB & WC/NS & MS & BC & N \\
\hline 61 & 17 & 4 & 3 & 16 & $10 / 3$ & 2 & 8 & 63 \\
62 & 23 & 5 & 1 & - & - & - & - & 29 \\
63 & 10 & 6 & 4 & - & $1 /-$ & - & - & 21 \\
64 & 19 & 5 & 1 & 5 & - & - & - & 30 \\
65 & 9 & 3 & - & 1 & - & - & - & 13 \\
68 & 19 & 7 & - & 1 & - & - & - & 27 \\
70 & 24 & 2 & 1 & 2 & $1 /-$ & - & - & 30 \\
71 & 11 & 1 & - & - & $1 /-$ & - & - & 13 \\
\hline Totals & 132 & 33 & 10 & 25 & $13 / 3$ & 2 & 8 & 226 \\
\hline
\end{tabular}

$\mathrm{DS}=$ decorated sherds; $\mathrm{PS}=$ plain sherds; $\mathrm{LD}=$ lithic debris; $\mathrm{AB}=$ animal bone; $\mathrm{WC}=$ wood charcoal; $\mathrm{NS}=$ nutshell; MS=mussel shell; $\mathrm{BC}=$ burned clay

By depth, the densities of artifacts, especially plain and decorated ceramic sherds, are highest between 0-60 cm bs, but there are significant numbers (27 percent) from $60-100 \mathrm{~cm} \mathrm{bs}$, most likely from feature contexts (Table A-2). Animal bone is present from 20-100 cm bs, while pieces of wood charcoal are present from 0-100 cm bs in these shovel tests. Mussel shell fragments occur from 20-40 and 80-100 $\mathrm{cm}$ bs. Burned clay, including some pieces with adhering ash chunks, are present from $20-80 \mathrm{~cm}$ bs.

Table A-2. Depth of artifacts recovered in ST 61-71 at the Bowles Creek site.

\begin{tabular}{lllllllll}
\hline $\begin{array}{l}\text { Depth } \\
\text { (cm bs) }\end{array}$ & DS & PS & LD & AB & WC/NS & MS & BC & N \\
\hline $0-20$ & 35 & 10 & 3 & - & $1 /-$ & - & - & 49 \\
$20-40$ & 36 & 11 & 2 & 5 & $1 /-$ & 1 & 3 & 59 \\
$40-60$ & 35 & 8 & 3 & 7 & $2 /-$ & - & 2 & 51 \\
$60-80$ & 21 & 1 & 2 & 5 & $6 / 3$ & - & 3 & 20 \\
$80-100$ & 5 & 3 & - & 8 & $3 /-$ & 1 & - \\
\hline Totals & 132 & 33 & 10 & 25 & $13 / 3$ & 2 & 8 & 226 \\
\hline
\end{tabular}

$\mathrm{DS}=$ decorated sherd; $\mathrm{PS}=$ plain sherd; $\mathrm{LD}=$ lithic debris; $\mathrm{AB}=$ animal bone; $\mathrm{WC}=$ wood charcoal; $\mathrm{NS}=$ nutshell; $\mathrm{MS}=$ mussel shell; BC=burned clay

The sherds from ST 61-71 are predominantly from grog-tempered vessels (91.5 percent), particularly the plain wares and fine wares (Table A-3). Approximately 12 percent of the utility ware sherds - all from brushed vessels - are from bone-tempered wares, likely jars. 
Table A-3. Ceramic wares in ST 61-71 from the Bowles Creek site.

\begin{tabular}{lccc}
\hline Ware & Grog-tempered & Bone-tempered & N \\
\hline Plain & 33 & - & 33 \\
Utility & 100 & 14 & 114 \\
Fine & 18 & - & 18 \\
\hline Totals & 151 & 14 & 165 \\
\hline
\end{tabular}

About 86 percent of the decorated sherds in this assemblage are from utility wares, and the remainder are from fine wares. More than 76 percent of all the decorated sherds have brushing marks, either as the sole decorative element (Bullard Brushed), or in combination with incised (Spradley BrushedIncised), brushed-punctated, or brushed-punctated-incised elements (Table A-4). The other utility wares in this assemblage include body sherds from Lindsey Grooved vessels, sherds with incised elements (4.5 percent), incised-punctated ( 0.8 percent), Killough Pinched ( 0.8 percent), punctated elements ( 0.8 percent), and one plain rim with a notched lip.

Table A-4. Decorative methods and decorative elements represented in ST 61-71 from the Bowles Creek site.

\begin{tabular}{llll}
\hline Decorative method and decorative element & Rim & Body & $\mathrm{N}$ \\
\hline
\end{tabular}

\section{Utility Ware}

\section{Brushed}

horizontal brushed

horizontal and diagonal brushed

opposed brushed

parallel brushed

$\begin{array}{lll}2 & - & 2 \\ - & 1 & 1 \\ - & 6 & 6 \\ - & 87 & 87\end{array}$

\section{Brushed-Incised}

parallel brushed and overlying parallel incised lines

parallel brushed and overlying diagonal incised lines

\section{Brushed-Punctated}

parallel brushed with tool punctated row through the brushing

\section{Brushed-Punctated-Incised}

parallel brushed, tool punctated rows through the

2
67

brushing, and overlying straight incised line

Grooved

straight groove

\section{Grooved-Brushed}


Table A-4. Decorative methods and decorative elements represented in ST 61-71 from the Bowles Creek site, cont.

\begin{tabular}{llll}
\hline Decorative method and decorative element & Rim & Body & N \\
\hline
\end{tabular}

\section{Utility Ware, cont.}

\section{Incised}

horizontal incised line

parallel incised lines

straight incised line

$\begin{array}{lll}- & 1 & 1 \\ - & 2 & 2 \\ - & 3 & 3\end{array}$

Incised-Punctated

straight incised line and adjacent tool punctated row

$\begin{array}{ccc}- & 1 & 1\end{array}$

Notched

regular notching along the lip

Pinched

single pinched ridge

$\begin{array}{clc}- & 1 & 1\end{array}$

\section{Punctated}

single large tool punctation

$-$

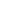

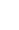

Fine Ware

\section{Engraved}

curvilinear engraved line

curvilinear excised zone or bracket

curvilinear engraved lines with excised tick marks

diagonal opposed engraved lines

excised triangular tick marks in a row

horizontal engraved line with excised tick marks

opposed engraved lines

parallel engraved lines with excised tick marks

straight engraved line

straight engraved line with excised tick marks

$\begin{array}{lll}- & 1 & 1 \\ - & 1 & 1 \\ - & 2 & 2 \\ - & 1 & 1 \\ - & 1 & 1 \\ 1 & - & 1 \\ - & 1 & 1 \\ - & 1 & 1 \\ - & 3 & 3 \\ - & 5 & 5\end{array}$

Trailed

curvilinear trailed lines

$-\quad 1$

1

1

Totals

4

128

132

The fine ware sherds include one Keno Trailed body sherd (Figure A-2a) as well as 17 engraved rim and body sherds (see Table A-4). Most of the engraved sherds $(n=10)$ in this assemblage are from Patton Engraved vessels (Figure A-2b-f) with excised tick marks on horizontal or curvilinear engraved lines, but there is also one Poynor Engraved, var. Cook body sherd (Figure A-2g), and another body sherd with diagonal opposed engraved lines (Figure A-2h). 


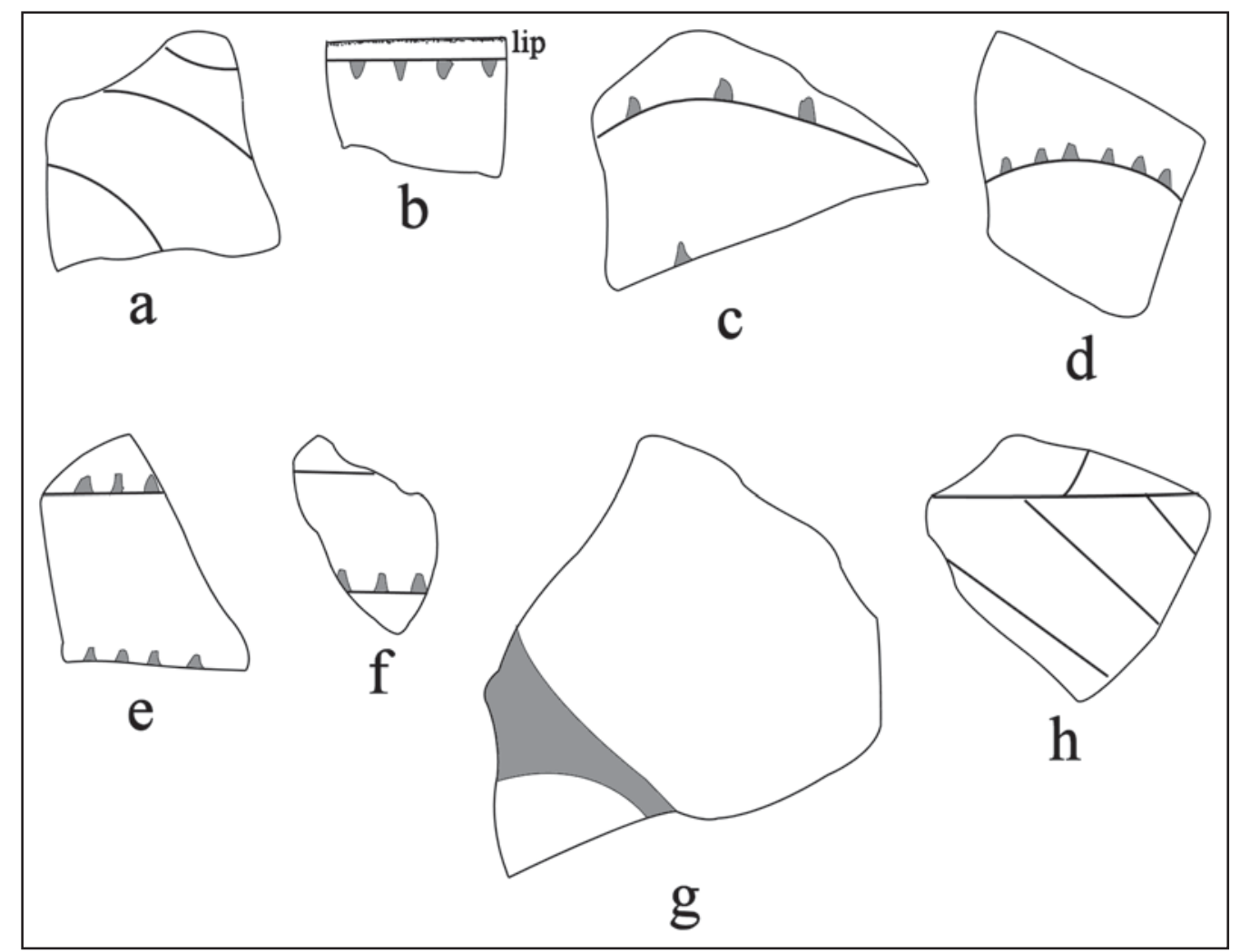

Figure A-2. Selected decorative elements on fine ware sherds from ST 61-71 at the Bowles Creek site.

The overall ceramic sherd assemblage from various investigations at the Bowles Creek site is summarized in Table A-5. The assemblage is dominated by brushed utility ware vessel sherds ( 82.8 percent of the decorated sherds), as well as vessels manufactured with grog temper. Incised or punctated vessels comprise a distinct minority of the utility wares from the site (7.0 percent). Only 5.9 percent of all the sherds, and 8.6 percent of the decorated sherds, are from fine ware engraved and trailed vessels, including sherds from Patton Engraved, Poynor Engraved, and Keno Trailed types.

Table A-5. Ceramic sherd assemblage summary from the Bowles Creek site (41CE475).

\begin{tabular}{ll}
\hline Attribute & Bowles Creek Site \\
\hline No. of sherds & 1703 \\
No. of decorated sherds & 1179 \\
Plain ware & $30.8 \%$ \\
Utility ware & $63.3 \%$ \\
Fine ware & $5.9 \%$ \\
& \\
P/DR & 0.44 \\
Brushed/Plain Ratio & 1.86 \\
Brushed/OWP Ratio & 7.05 \\
& \\
Grog-tempered & $89.3 \%$ \\
Bone-tempered & $10.7 \%$
\end{tabular}


Table A-5. Ceramic sherd assemblage summary from the Bowles Creek site (41CE475), cont.

\begin{tabular}{ll}
\hline Attribute & Bowles Creek Site \\
\hline Engraved & $7.9 \%$ \\
Engraved-brushed & $0.2 \%$ \\
Engraved-punctated & $0.2 \%$ \\
Trailed & $0.3 \%$ \\
& \\
Brushed & $80.0 \%$ \\
Brushed-Appliqued & $0.1 \%$ \\
Brushed-Incised & $1.4 \%$ \\
Brushed-Punctated & $1.3 \%$ \\
Grooved & $0.6 \%$ \\
Incised & $5.1 \%$ \\
Incised-Punctated & $0.3 \%$ \\
Neck Banded & $0.3 \%$ \\
Notched & $0.1 \%$ \\
Pinched & $0.7 \%$ \\
Punctated & $1.9 \%$ \\
\hline
\end{tabular}

$\mathrm{P} / \mathrm{DR}=$ plain/decorated sherd ratio; $\mathrm{OWP}=$ other wet paste sherds

Ten pieces of lithic debris are present in ST 61-71 (see Table A-1). They include pieces of petrified wood $(n=3,33$ percent cortical), quartzite $(n=1,100$ percent cortical), brownish-gray chert $(n=1,0$ percent cortical), gray chert $(n=2,0$ percent cortical), and dark gray chert $(n=3,0$ percent cortical).

The eight pieces of burned clay, and the two pieces of mussel shell, were recovered from ST 61 (see Table A-1). Sixteen of the 25 pieces of animal bone (64 percent) are also from ST 61, most from 60-100 cm bs.

Factoring in the findings from ST 61-71, the shovel tests indicate that there is one ca. 40 x $20 \mathrm{~m}$ concentration of ceramic sherds not far north of the creek channel at the Bowles Creek site (Figure A-3a). Shovel tests in this area have sherd densities that range from ca. 120-232 sherds per square meter. A smaller $30 \times 20 \mathrm{~m}$ area of the site has preserved animal bones, mussel shell pieces, and charred plant remains, with the highest densities in ST 61, ST 52, and ST 64 (Figure A-3b). The few pipe sherds and the burned clay pieces found in the shovel testing occur in only three shovel tests within the single ca. 40 x $20 \mathrm{~m}$ ceramic vessel sherd concentration at the site (Figure A-3c). 

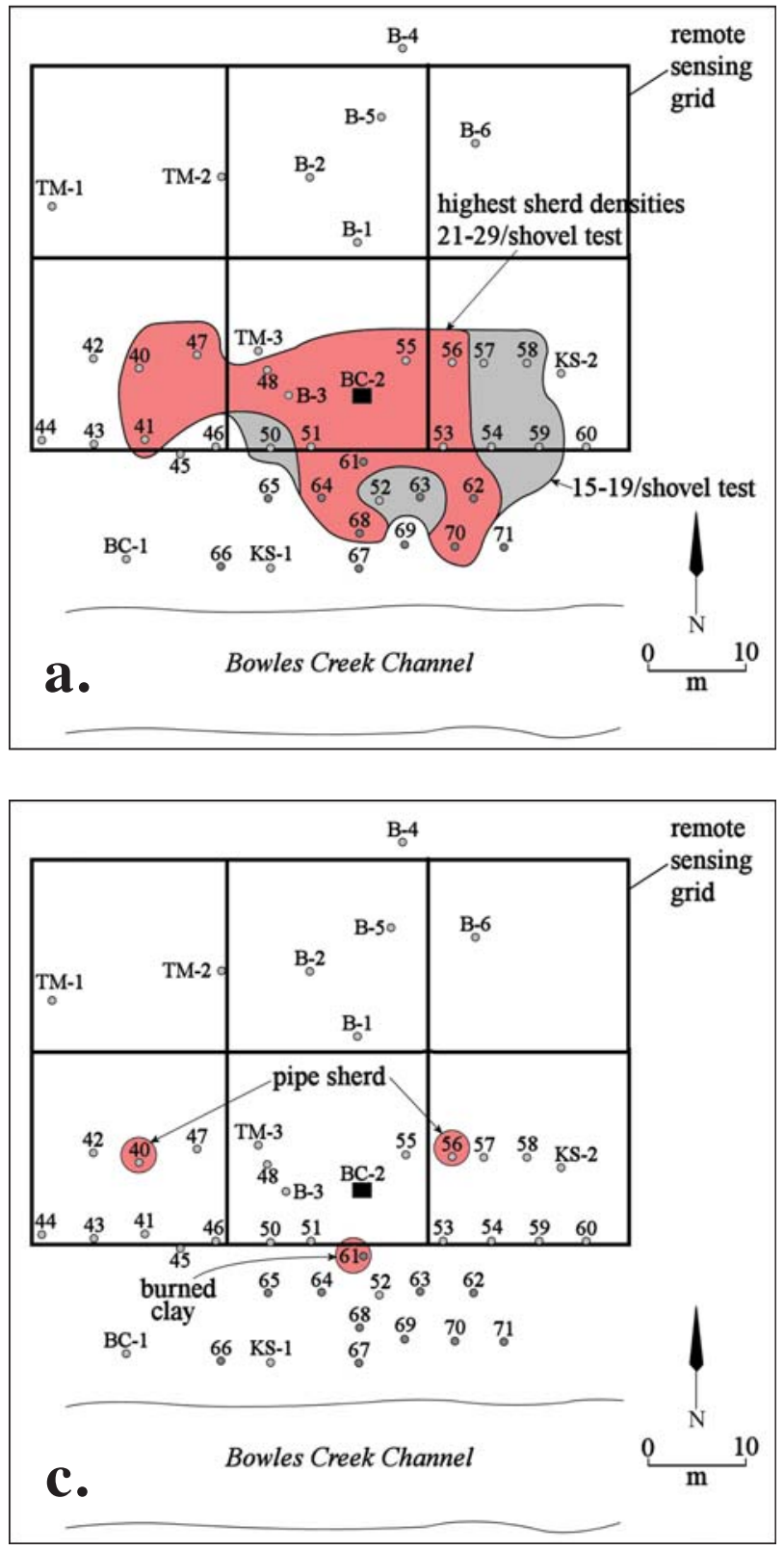

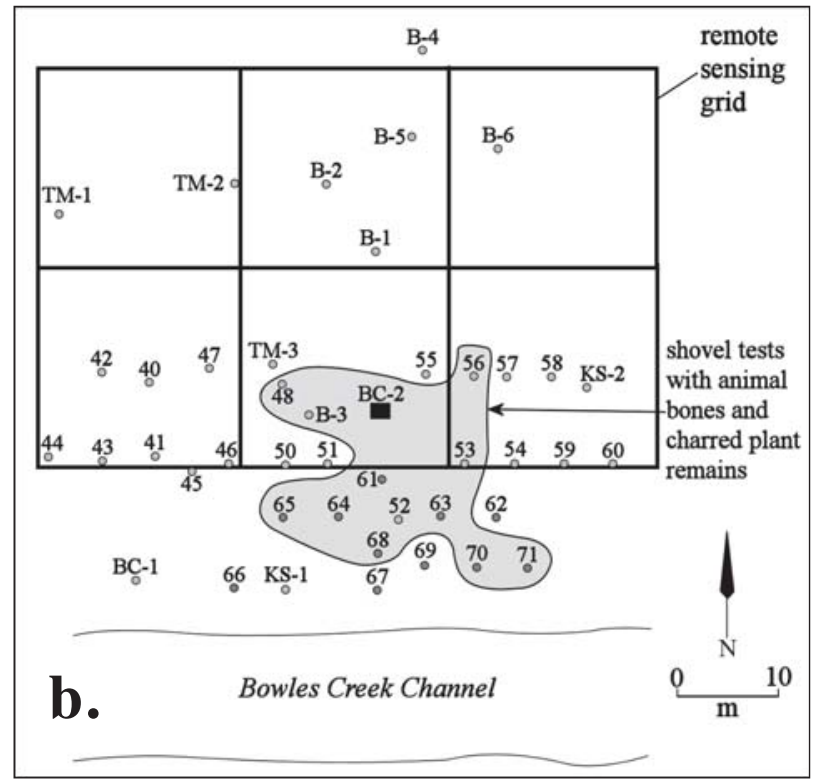

Figure A-3. Spatial distribution of artifacts in the Bowles Creek site: a, ceramic sherds; b, animal bones and charred plant remains; c, ceramic pipe sherds and burned clay pieces. 